\title{
Phytochemistry and Biological Activities of Amburana cearensis (Allemão) ACSm
}

\author{
Zildene de Sousa Silveira ${ }^{1,2}{ }^{(}$, Nair Silva Macêdo $\left.{ }^{1,2}{ }^{(}\right)$, Suieny Rodrigues Bezerra ${ }^{1}$, Abolghasem Siyadatpanah ${ }^{3, *}$, \\ Henrique Douglas Melo Coutinho ${ }^{4, *}{ }^{\infty}$, Zahra Seifi ${ }^{5}$, Bonglee Kim ${ }^{6,7, *(\mathbb{D})}$, Francisco Assis Bezerra da Cunha ${ }^{1}$ \\ and Valdir de Queiroz Balbino ${ }^{2}$
}

\section{check for}

updates

Citation: Silveira, Z.d.S.; Macêdo, N.S.; Bezerra, S.R.; Siyadatpanah, A.; Coutinho, H.D.M.; Seifi, Z.; Kim, B.; da Cunha, F.A.B.; Balbino, V.d.Q. Phytochemistry and Biological Activities of Amburana cearensis (Allemão) ACSm. Molecules 2022, 27, 505. https://doi.org/10.3390/ molecules27020505

Academic Editor: José Carlos Tavares Carvalho

Received: 1 December 2021

Accepted: 11 January 2022

Published: 14 January 2022

Publisher's Note: MDPI stays neutral with regard to jurisdictional claims in published maps and institutional affiliations.

Copyright: (c) 2022 by the authors Licensee MDPI, Basel, Switzerland. This article is an open access article distributed under the terms and conditions of the Creative Commons Attribution (CC BY) license (https:// creativecommons.org/licenses/by/ $4.0 /)$.
1 Laboratory of Semi-Arid Bioprospecting (LABSEMA), Regional University of Cariri-URCA, Crato 63105-000, Brazil; zildenesousa15@gmail.com (Z.d.S.S.); naiirmacedo@gmail.com (N.S.M.); annesofiacrato@gmail.com (S.R.B.); cunha.urca@gmail.com (F.A.B.d.C.)

2 Graduate Program in Biological Sciences-PPGCB, Federal University of Pernambuco-UFPE, Recife 50670-901, Brazil; valdir.balbino@ufpe.br

3 Ferdows School of Paramedical and Health, Birjand University of Medical Sciences, Birjand 97178-53577, Iran

4 Laboratory of Microbiology and Molecular Biology (LMBM), Regional University of Cariri-URCA, Crato 63105-000, Brazil

5 Laboratory Sciences Research Center, Golestan University of Medical Sciences, Gorgan 49189-36316, Iran; zhrseifi@gmail.com

6 Department of Pathology, College of Korean Medicine, Kyung Hee University, Seoul 02447, Korea

7 Korean Medicine-Based Drug Repositioning Cancer Research Center, College of Korean Medicine, Kyung Hee University, Seoul 02447, Korea

* Correspondence: asiyadatpanah@yahoo.com (A.S.); hdmcoutinho@urca.br (H.D.M.C.); bongleekim@khu.ac.kr (B.K.)

Abstract: Amburana cearensis (Allemão) ACSm. belongs to the Fabaceae family and occurs in the Brazilian semiarid, Argentina, Paraguay, Bolivia, and Peru. Numerous studies that portray its ethnobotany, use in popular medicine, chemical composition, and biological activities exist in the literature. This review aimed to provide an overview of the chemical composition, ethnopharmacology, and biological activities associated with $A$. cearensis and its isolated constituents. Information was collected from internet searches in the Scopus, Medline, PubMed, Google Scholar, and ScienceDirect databases were performed covering publications from 1997-2020. An ethnopharmacological literature analysis revealed that $A$. cearensis is used to treat a wide range of respiratory disorders in addition to intestinal, circulatory, and inflammatory problems. Coumarins, flavonoids, phenolic glycosides, phenolic acids, phenylpropanoid derivatives, and triterpenoids, among others, have been reported as active compounds, with High-Performance Liquid Chromatography (HPLC) being the main analytical technique used. The $A$. cearensis extracts and compounds presented several biological activities, including antimicrobial, antinociceptive, anti-inflammatory, antioxidant, neuroprotective, and myorelaxant activities, among others. This review provides a useful bibliography for future investigations and $A$. cearensis applications; however, future studies should focus on its toxic effects and the mechanisms of action of its extracts and isolated constituents to guide clinical applications.

Keywords: Amburana cearensis; ethnopharmacology; phytochemistry; pharmacology; coumarins

\section{Introduction}

Since the beginning of human civilization, natural products such as plants have been used to treat and cure various diseases [1]. According to data from the World Health Organization (WHO), roughly $80 \%$ of the population in developing countries use phytotherapics to meet needs associated with primary health care [2]. Thus, investment in research that focuses on investigating the bioactivity of phytotherapic products has grown in recent decades. The majority of the interest lies within the field of active constituents, which are present in the composition of these products and can be effective sources for 
the development of bioactive derivatives with less side effects, lower costs, and thus greater accessibility [3]. Fabaceae is within the families of plants used in popular medicine. Fabaceae is also within the largest families of angiosperms, second only to Orchidaceae and Asteraceae, encompassing over 700 genera and roughly 20,000 species that are distributed worldwide [4]. In addition, Fabaceae is the second largest family, with approximately 490 species that are used in traditional medicine [5]. Amburana cearensis (Allemão) ACSm., popularly known as "imburana-de-odor", "cumaru", and "cerejeira", among other names, is a plant species belonging to the Fabaceae family (Leguminoseae, Papilionoideae) that is well distributed in the semiarid regions of Brazil [6]. Different parts of this plant, such as the stem bark, leaves, and seeds, are widely used in popular medicine in the form of teas, infusions, and decoctions for the treatment of respiratory system disorders, such as asthma, sinusitis, bronchitis, influenza, and other purposes [7,8].

Despite the numerous biological activities that have been attributed to A. cearensis in the literature, a review of the plant's bioactivities does not yet exist. Therefore, the present study aimed to systematically review the phytochemical composition, uses in traditional medicine, and bioactivities associated with $A$. cearensis as well as with some of its isolated compounds.

\section{Materials and Methods}

\subsection{Literature Search Strategy}

The name of the plant was verified using the websites www.theplantlist.org (The Plant List, 2013) (accessed on 30 November 2021) and www.ipni.org (International Plant Name Index) (accessed on 30 November 2021), with synonyms with three levels of confidence being considered. For data collection, a comprehensive search of scientific articles was performed using the following databases: Scopus, Medline, PubMed, Google Scholar, and ScienceDirect, using the following descriptors: "Amburana cearensis; Amburana cearensis and activities" in addition to its synonymous names Torresea cearensis and Amburana claudii, which have also been used to refer to this species but are not currently accepted names. Studies published from 1997 up to March 2020 were reviewed. Full-text articles were selected if the title, abstract, or keywords included the aforementioned descriptors.

\subsection{Exclusion and Inclusion Criteria}

Studies excluded from the review included ref. [1] studies that did not fall under the original study category (letters to the editor, prefaces, comments, editorials, reviews, books, book chapters, theses, and dissertations); ref. [2] repeated studies; and [3] case reports. Articles were selected based on their title, abstract, and keywords. Lastly, full articles were analyzed according to the following criteria: ref. [1] botanical aspects; ref. [2] phytochemistry; ref. [3] ethnopharmacological uses; ref. [4] bioactivities; and [5] bioactivities of isolated $A$. cearensis constituents.

\section{Results and Discussion}

Eventually, a total of 5214 studies were obtained after searching the databases. Following the selection steps based on the established inclusion and exclusion criteria, 70 articles were selected for data extraction and for the interpretation of their results. The analyzed data are discussed in the sections below.

\subsection{Botanical Aspects}

Amburana cearensis (Allemão) ACSm. is an arboreal species from the Fabaceae family (Leguminoseae, Papilionoideae) that is typical to open and deciduous tropical forests and is commonly found in Brazilian caatinga and cerrado regions. However, reports of the presence of this genus also exist in northern Argentina, Paraguay, Bolivia, and southeastern Peru [9,10]. According to "The Plant List" (www.theplantlist.org) (accessed on 30 November 2021), the Amburana genus has two species, Amburana cearensis (Allemão) ACSm and Amburana acreana (Ducke) ACSm. A. cearensis is characterized by its upright, 
brown colored stems that can reach 10 to $12 \mathrm{~m}$ in height [9]. A. cearensis has unique fruits, including Papilionoideae, that vary from green with yellowish spots to dark brown spots when dry has a wrinkled and dehiscent aspect, with winged seeds that are inside a thin membranous endocarp envelope and have an anemochory dispersion [11,12]. A. cearensis seeds are stenospermic, with a shape that varies between elliptical, oblong, and ovoid, with an average biometry of $14.4 \mathrm{~mm}$ in height, $10.4 \mathrm{~mm}$ in width, and $4.7 \mathrm{~mm}$ in thickness. A. cearensis seed integuments have a woody texture with a brown and opaque color and a very visible hilum that is elliptical in shape $[13,14]$. Its leaves are composed of 7 to 15 leaflets, which are elliptical to oval in shape, with an obtuse apex and rounded base. The inflorescences are between 2 and $5 \mathrm{~cm}$ long [6].

\subsection{Uses in Popular Medicine}

Traditional plants present a huge diversity of phytocompounds with possible applications against several diseases due the possible discovery of many medicines for clinical use [15]. Traditionally, Amburana cearensis is used by the quilombola and indigenous communities in Bolivia and northeastern Brazil for medicinal purposes [16-18]. The Chacobo Bolivian ethnic group (Department of Beni), who live in an endemic malaria region, use an aqueous decoction from the A. cearensis bark to combat fevers [19], whereas the Tocana ethnic group (Department of La Paz, Bolivia) uses the bark in the form of decoctions to treat abdominal and kidney pain and in the form of baths to treat rickets.

A. cearensis has extensive usage in popular medicine, where its bark, seeds, and fruits have been used, especially by populations in the semiarid regions of Brazil, for the treatment of respiratory system diseases such as bronchitis, asthma, rhinitis, flu, cough, and sinusitis and as an expectorant in the forms of a decoction, oral ingestion, and gargle [8,20-22]. The plant is also highly indicated for intestinal problems, colic, diarrhea, placental delivery, headaches, whooping cough, thrombosis, hypertension, heartburn, skin ulcers, urinary infections, dehydration, emesis, joint pain, vertigo, and fever and has been used as a depurative and diuretic to treat kidney infections as well as an antispasmodic, cicatrizing agent, tonic, and anti-anemic for fungal dermatitis, and as an antiophidic in the event of snake bites and sores [23-27].

Reports on the use of its bark together with other medicinal herbs in the form of syrups and macerations against fatigue and as an expectorant can also be found in the literature [28,29]. An immersion of bark in water is used in the form of baths to combat skin, throat, and gynecological inflammations [30]. The literature also reports the use of the bark and seed oil against parasitic worms, general pain, circulation problems, and wound healing [7].

\subsection{Phytochemistry}

Phytochemical investigations are important for the discovery of new bioactive phytocompounds and for the exploration of a plant's compounds for the treatment of diseases [31]. The phytochemical characterization of different $A$. cearensis parts has been carried out by several groups in recent decades by using different analytical techniques. The isolated chemical components are mainly coumarins, flavonoids, phenolic acids, glycosylated phenols, phenylpropanoid derivatives, and triterpenoids. A summary of the phytochemical data is shown in Table 1.

\subsubsection{Stem Bark}

Chemical composition analysis of $A$. cearensis bark extracts resulted in the isolation of coumarin and amburoside A and B [19]. Negri et al. [32] identified coumarins such as dihydrocoumarin and scopoletin; the methyl phenylpropanoid trans-3,3-dimethoxycinnamate; the benzoic acid methyl 3-methoxy-4-hydroxy benzoate; simple phenols such as catechol and guaiacol and the anthraquinone chrysophanol in addition to the triterpenoids lupeol and amyrin; and the steroid $\gamma$-sitosterol and the methyl ester methyl palmitate. 
In the phytochemical analysis of the ethanolic extract of the bark of $A$. cearensis performed by Canuto and Silveira [33], the presence of several compounds was identified, such as coumarin; the phenolic acids vanillic acid and protocatechuic acid; flavonoids afrormosin, isokaempferide, kaempferol, quercetin, and $4^{\prime}$-methoxy-phiseti; and the phenolic glycoside amburoside A and a mixture of glycosylated $\beta$-sitosterol and stigmasterol. Canuto et al. [34] identified amburoside A and six new amburosides $(\mathrm{C}-\mathrm{H})$ : 6-coumaryl protocatechuate, 6-hydroxycoumarin, isokaempferide, formononetin, vanillic acid, and (E)-o-coumaric acid. Leal et al. [35] also identified protocatechuic and vanillic acids in addition to coumarin and amburoside A. Sá et al. [36] showed the presence of 4-methoxy-3-methylphenol and tricyclene as well as the terpenoids $\alpha$-pinene, $\beta$-pinene, and 4-hydroxybenzoic acid.

\subsubsection{Seeds}

Costa et al. [37] reported the presence of coumarins, and L-ascorbic acid and gallic acid, ellagic acid, catechin, rutin, naringin, myricetin, and morin have also been identified [38].

The investigation of the metabolic profile of the A. cearensis seed extract performed by Pereira et al. [39] identified coumarin and 3-methyl-coumarin; fatty acid esters with methyl hexadecanoate, 9-cis-11-trans-octadecadienoate, methyl 13-trans-methyl-octadecanoate, and 9,12-cis-9-ethyl octadecenoate; the fatty acids hexadecanoate acetate, octadecanoate acetate, and ett octadecanoate; the steroids $\gamma$-sitosterol, campesterol, and stigmasterol; and the triterpenoid $\beta$-amyrin.

Analysis of the seed oil fatty acid profile revealed the presence of oleic (50.1\%), palmitic $(15.7 \%)$, linoleic $(9.7 \%)$, stearic $(5.3 \%)$, linolenic $(5.0 \%)$, behenic $(3.9 \%)$, arachidonic $(2.4 \%)$, lignoceric $(2.2 \%)$, lauric $(0.6 \%)$, myristic $(0.3 \%)$, and margarine $(0.2 \%)$ [40].

\subsubsection{Leaves}

Gouveia et al. [41] identified the presence of phenolic compounds such as protocatechuic acid, epicatechin, $p$-coumaric acid, gallic acid, and kaempferol in A. cearensis leaf ethanolic extract through HPLC analysis.

\subsubsection{Resin}

Oliveira et al. [42] analyzed the $A$. cearensis resin, characterizing its constituents as follows: dilmin, lulin, erycibenin $\mathrm{D}, 7,8,3^{\prime}$-trihydroxy-4' ${ }^{\prime}$-methoxyisoflavone, 7,8,3'trihydroxy-6, $4^{\prime}$-dimethoxyisoflavone, $3^{\prime}$-dihydroxy-8, $4^{\prime}$-dimethoxyisoflavone, calycosin, odoratin, butein, cladrastrin, pratensein, $3^{\prime}, 4^{\prime}$-dimethoxy-1'-(7-methoxy-4-oxo-4H-chromen3 -yl)benzo-2' $5^{\prime}$-quinone, isoliquiritigenin, and homobutein.

\subsubsection{Cultivated Young Plants}

Canuto et al. [43] investigated the phytochemical profile of cultivated young A. cearensis specimens, where coumarins, isokaempferidium, amburoside $A$ and $B$, vanillic acid, $p$-hydroxybenzoic and aiapin acid, glycosylated (E/Z)-o-coumaric acid, and protocatechuic acid were identified in the ethanolic extract from young plants. Leal et al. [35] also detected vanillic acid and coumarins as constituents of the aerial parts in their study.

\subsection{Bioactivities Attributed to Amburana Cearensis}

Many of the medicinal properties of A. cearensis, such as anti-inflammatory, antinociceptive, antimicrobial, and others, have scientific support through in vivo and in vitro assays, as evidenced in this review, which justifies the application of this plant for medicinal purposes. Moreover, new evidence about other bioactivities as acaricidal, repellent, photoprotective, among others, have been observed. The major part of these studies were performed using bark extracts and fractions, with only nine compounds being evaluated for their pharmacological effects (Figure 1). The list of the ethnomedicinal scientific results available for this species are listed below. The biological properties of the crude extracts are summarized in Table 2, while their isolated phytochemicals have been compiled in Table 3. 
Table 1. Chemical compounds identified in A. Cearensis by differents analytical techniques.

\begin{tabular}{|c|c|c|c|c|}
\hline Part Used & Solvents & $\begin{array}{l}\text { Analytical } \\
\text { Technique }\end{array}$ & Compounds & Citations \\
\hline \multirow[t]{6}{*}{ Stem bark } & $\begin{array}{l}\text { Petrol, } \mathrm{CH}_{2} \mathrm{Cl}_{2} \text {, and } \\
\quad \text { ethyl acetate }\end{array}$ & VLC & Coumarin and amburoside A and B & {$[19]$} \\
\hline & $\begin{array}{l}\text { Hexane, chloroform, } \\
\text { ethyl acetate, acetone, } \\
\text { and methanol }\end{array}$ & GC/EIMS & $\begin{array}{c}\text { Dihydrocumarin; scopoletin; } \\
\text { trans-methyl-3,4-dimethoxy cinnamate; } \\
\text { methyl-3-methoxy-4-hydroxy benzoate; cathecol; } \\
\text { guaiacol; chrysophanol; lupeol; amyrins; } \\
\text { } \gamma \text {-sitosterol; methyl palmitate }\end{array}$ & [32] \\
\hline & Ethanol & HPLC & $\begin{array}{c}\text { Coumarin; } \\
\text { vanillic acid and protocatechuic acid; afrormosin; } \\
\text { isokaempferide; kaempferol; quercetin; } \\
4^{\prime} \text {-methoxy-fisetin; amburoside A; } \beta \text {-sitosterol } \\
\text { and stigmasterol }\end{array}$ & [33] \\
\hline & Hexane & HPLC & $\begin{array}{l}\text { Amburosides (A and C-H); 6-coumaryl } \\
\text { protocatechuate; 6-hydroxycoumarin, } \\
\text { isokaempferide, formononetin, vanillic acid, and } \\
(E) \text {-o-coumaric acid }\end{array}$ & {$[34]$} \\
\hline & Chloroform & GC/MS & $\begin{array}{l}\text { 4-methoxy-3-methylphenol; tricyclene; } \alpha \text {-pinene; } \\
\beta \text {-pinene and 4-hydroxybenzoic acid }\end{array}$ & [36] \\
\hline & Ethanol & HPLC & $\begin{array}{c}\text { Protocatechuic acid; } \\
\text { vanillic acid; } \\
\text { coumarin and amburoside A }\end{array}$ & [35] \\
\hline \multirow[t]{3}{*}{ Seeds } & $\begin{array}{l}\text { Hexane, } \\
\text { dichloromethane, ethyl } \\
\text { acetate, and ethanol }\end{array}$ & GC/MS & Coumarin, gallic acid, and L-ascorbic acid & {$[37]$} \\
\hline & $\begin{array}{l}\text { Ethanol, hexane, } \\
\text { dichloromethane and } \\
\text { ethyl acetate }\end{array}$ & HPLC & $\begin{array}{l}\text { Coumarin; 3-methyl-coumarin; methyl } \\
\text { hexadecanoate; methyl } \\
\text { 9-cis-11-trans-octadecadienoate; methyl } \\
\text { 13-trans-methyl-octadecanoate; methyl } \\
\text { hexadecanoate; ethyl hexadecanoate; } \\
\text { octadecanoate acetate; } 9,12 \text {-cis-9-ethyl } \\
\text { octadecanoate; ethyl octadecanoate; } \gamma \text {-sitosterol; } \\
\text { campesterol; stigmasterol and } \beta \text {-amyrin }\end{array}$ & [39] \\
\hline & Ethanol & HPLC & $\begin{array}{l}\text { Gallic acid; catechin; rutin; ellagic acid; naringin; } \\
\text { myricetin and morin }\end{array}$ & [38] \\
\hline Leaves & Ethanol & HPLC/DAD & $\begin{array}{l}\text { Protocatechuic acid; } \\
\text { Epicatechin; } p \text {-coumaric acid; gallic acid; } \\
\text { and kaempferol }\end{array}$ & [41] \\
\hline Resin & Methanol & $\begin{array}{l}\text { UPLC-DAD-QTOF- } \\
\text { MS/MS) }\end{array}$ & 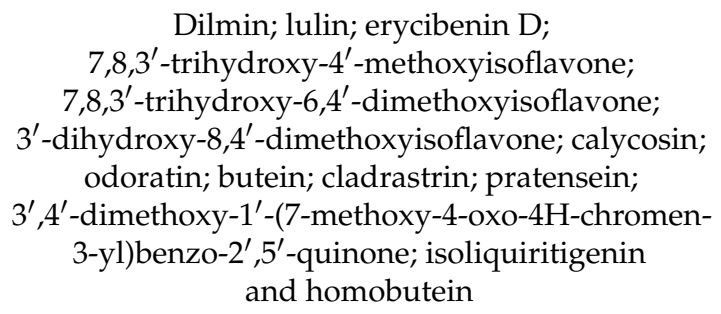 & {$[42]$} \\
\hline
\end{tabular}


Table 1. Cont.

\begin{tabular}{|c|c|c|c|c|}
\hline Part Used & Solvents & $\begin{array}{l}\text { Analytical } \\
\text { Technique }\end{array}$ & Compounds & Citations \\
\hline \multirow[t]{3}{*}{$\begin{array}{l}\text { Young } \\
\text { cultivated } \\
\text { plants }\end{array}$} & Ethanol & HPLC & $\begin{array}{l}p \text {-hydroxybenzoic acid; ayapin, }(E / Z)-o \text {-coumaric } \\
\text { acids coumarin and isokaempferide; vanillic acid, } \\
\text { protocatechuic acid; amburosides A and B }\end{array}$ & [43] \\
\hline & Ethanol & HPLC & Vanillic acid and coumarin & [35] \\
\hline & & $\begin{array}{l}\text { quid chromatc } \\
\text { formance liqu } \\
\text { gh-performanc } \\
\text { performance } \\
\text { try. }\end{array}$ & $\begin{array}{l}\text { y; GC/EIMS: gas chromatography with electron impact ma } \\
\text { matography; GC/MS: gas chromatography coupled to ma } \\
\text { d chromatography equipped with a diode array detector; UI } \\
\text { hromatography coupled with diode array and quadrup }\end{array}$ & $\begin{array}{l}\text { spectrometry } \\
\text { spectrometry } \\
\text { C-DAD-QTOI } \\
\text { time-of-fligh }\end{array}$ \\
\hline
\end{tabular}

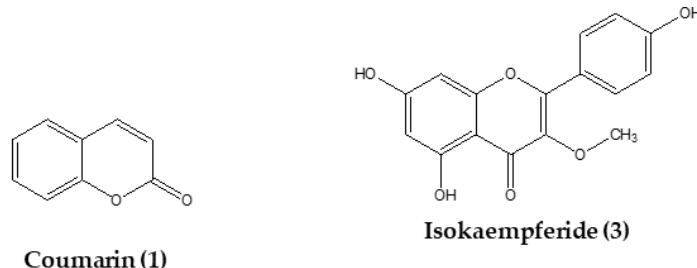

Coumarin (1)

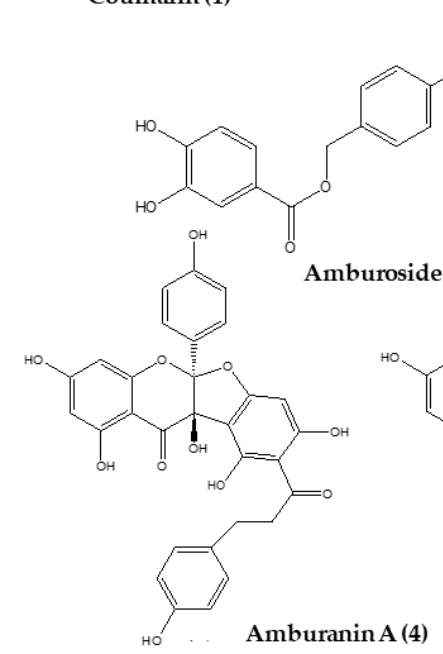

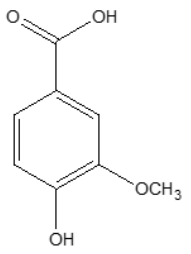

Vanillic acid (6)<smiles>O=C(O)c1ccc(O)c(O)c1</smiles>

Protecatechuic acid (8)<smiles>COc1ccc(-c2coc3cc(O)c(OC)cc3c2=O)cc1</smiles>

Afrormosin (7)<smiles>O=c1c(O)c(-c2ccc(O)cc2)oc2cc(O)cc(O)c12</smiles>

Figure 1. Chemical structures of the main compounds from A. cearensis.

\subsubsection{Antimicrobial Activity}

The ethanolic extracts from the stem bark showed an antibacterial effect against Staphylococcus epidermidis, S. aureus, S. caprie, S. intermedius, Klebsiella spp., Salmonella spp., Pseudomonas aeruginosa, Escherichia coli, Enterococcus faecalis, Rhodococcus equi, Listeria spp., Corynebacterium spp., Aeromonas spp., Proteus spp, Yersinia enterocolitica, Streptococcus agalactiae, Streptococcus suis, Nocardia spp., Vibrio spp., Micrococcus spp., and Edwadisiella spp., with minimum bactericidal concentration (MBC) values ranging from 31.25 to $333.33 \mu \mathrm{L} / \mathrm{mL}[44]$.

The antibacterial activity of the leaf ethanolic extract was also demonstrated against the $S$. aureus SA-ATCC 25923 strain with a minimum inhibitory concentration (MIC) value of $512 \mu \mathrm{g} / \mathrm{mL}$. Despite direct antibacterial activity against $E$. coli (MIC $\geq 1024$ ) not being observed, a modulation of the aminoglycosides gentamicin and amikacin activity was noted, with decreases in MIC ranging from 64 to $4 \mu \mathrm{g} / \mathrm{mL}$ and from 128 to $8 \mu \mathrm{g} / \mathrm{mL}$, respectively, against E. coli 27 being recorded [45].

In their study, Silva et al. [46] also found antibacterial activity for the hydroalcoholic extract against Acinetobacter spp., with a mean MBC of $9.375 \mu \mathrm{g} / \mathrm{mL}$. The ethanolic extract, however, presented an average MBC value of $390.6 \mu \mathrm{g} / \mathrm{mL}$ against Enterobacter spp.; $1302 \mu \mathrm{g} / \mathrm{mL}$ against E. coli; and $911.4 \mu \mathrm{g} / \mathrm{mL}$ for the Klebsiella spp., genus. Similar results 
were found in assays performed by Peixoto et al. [47], where the A. cearensis bark ethanolic extract demonstrated an antibacterial potential with a mean MBC value $12,500 \mu \mathrm{g} / \mathrm{mL}$ against Staphylococcus spp. For the stem bark chloroform extract, inhibitory effects against P. aeruginosa and Bacillus cereus were also demonstrated, with MIC values of $6900 \mu \mathrm{g} / \mathrm{mL}$ being obtained for both strains [36].

In terms of the antibacterial activity of the seed extracts, the ethanolic extract was effective against $E$. coli $(25,922)$, S. aureus $(29,213)$, P. aeruginosa $(27,853)$, Listeria monocytogenes (35,152), and Shigella flexneri (700,930), with MIC values of 1000, 250, 250, 500, and $250 \mu \mathrm{g} / \mathrm{mL}$, respectively. An antibacterial effect for the seed aqueous extract against the same E. coli, S. aureus, P. aeruginosa, L. monocytogenes, and S. flexneri strains was also observed with MIC values of 1000, 1000,500,500, and $500 \mu \mathrm{g} / \mathrm{mL}$, respectively [38]. Oliveira et al. [48] evaluated the antibacterial activity of the $A$. cearensis seed crude extract and its fractions (fraction $1-0$ to $30 \%$; fraction $2-30-60 \%$; fraction $3-60-90 \%$, of ammonium sulfate saturation). The samples did not show direct antibacterial activity against the S. aureus (SA10) and E. coli (EC06) strains, both with MIC values $\geq 1024 \mu \mathrm{g} / \mathrm{mL}$. However, the $A$. cearensis seed crude extract and its fractions acted as antibiotic activity modifying agents, with a synergism being observed in the association between gentamicin and the crude extract against $E$. coli and $S$. aureus. Moreover, norfloxacin combined with the crude extract and fraction 1 also presented a significant synergism against E. coli and S. aureus. Likewise, gentamicin in combination with fractions 1 and 3 exhibited synergism against S. aureus. In addition, the combined effect of the crude extract and its fractions with penicillin demonstrated synergisms against $S$. aureus, while a synergism against $E$. coli was observed with the association between penicillin and the crude extract.

The isolated constituent 2-methoxy-4-methylphenol showed antibacterial activity with MIC values of 215, 215, 431, 431, 215, 215, and $215 \mu \mathrm{g} / \mathrm{mL}$ for Salmonella enterica Serotype Typhimurium, E. coli, P. aeruginosa, B. cereus, L. monocytogenes, S. aureus, and K. pneumoniae, respectively [36].

Many natural compounds with traditional usage have been investigated for their antimicrobial effects [49]. Regarding $A$. cearensis, its antibacterial potential is the strongest evidence of its traditional usage in treating gastrointestinal problems and infections of the urinary system [23].

The antifungal activity of the extracts and compounds isolated from $A$. cearensis is not well documented. However, the protein fraction from the seeds exhibited antifungal activity against different fungal species, presenting an inhibitory growth effect of up to $60 \%$ of the filamentous fungi Fusarium solani, Fusarium oxysporum, and Colletotrichum lindemuthianum at a concentration of $160 \mu \mathrm{g} / \mathrm{mL}$. The 80 and $160 \mu \mathrm{g} / \mathrm{mL}$ concentrations also significantly inhibited the growth of Saccharomyces cerevisiae and Candida albicans yeasts, showing inhibition of up to $80 \%$ at the $160 \mu \mathrm{g} / \mathrm{mL}$ concentration [50]. The good effect against fungi demonstrated the traditional usage in the tretatment of fungal dermatitis [26].

Although the action mechanisms of the extracts and their compounds against bacteria have not been evidenced in the studies analyzed, these effects are possibly due to interferences in lipid bilayers inducing bacterial membrane rupture and the inhibition of processes such as biofilm formation, cell envelope synthesis, nucleic acid synthesis, electron transport chain, and ATP synthesis in these microorganisms performed by secondary metabolites such as flavonoids, which have been considered to be promising sources for antimicrobial therapy [51].

\subsubsection{Anti-Inflammatory, Antinociceptive and Antiedematogenic Activities}

The Torresea cearensis (synonym of A. cearensis) bark hydroalcoholic extract reduced the nociception produced by acetic acid and formalin in a dose-dependent manner by 21 and $30 \%$ at the 100 and $200 \mathrm{mg} / \mathrm{kg}$ concentrations, respectively. The $200 \mathrm{mg} / \mathrm{kg}$ concentration also significantly inhibited carrageenan-induced paw edema by 30 and $48 \%$ within 3 and $4 \mathrm{~h}$, respectively [52]. The reduction of the nociceptive effect induced by acetic acid indicated the effect on the peripheral analgesy mechanisms [53]. 
Similar results were observed by Leal et al. [54], where the oral administration of the hydroalcoholic extract at 100 and $200 \mathrm{mg} / \mathrm{kg}$ inhibited the contortions induced by acetic acid by 21 and $49 \%$, respectively, in Wistar rats. The same concentrations also inhibited nociception by 19 and $60.1 \%$, respectively, during the 2nd stage of the formalin test. The $200 \mathrm{mg} / \mathrm{kg}$ concentration also reduced carrageenan-induced paw edema by $48 \%$ within $4 \mathrm{~h}$. Likewise, bark hydroalcoholic extract, when administered orally $(400 \mathrm{mg} / \mathrm{kg})$ or intraperitoneally $(200 \mathrm{mg} / \mathrm{kg})$, in BALB/c mice significantly inhibited antigen-induced paw edema and the production of immunoglobulin-specific ovalbumin by 50 to $80 \%$ [55]. As shown in the study by Leal et al. [56], the stem bark hydroalcoholic extract at concentrations of 200 and $400 \mathrm{mg} / \mathrm{kg}$ (administered orally) inhibited leukocyte and neutrophil migration by 37 and $42 \%$, respectively.

According to a study by Oliveira et al. [57] the stem bark ethanolic extract demonstrated antinociceptive activity at the 200 and $400 \mathrm{mg} / \mathrm{kg}$ doses. In addition, the 100, 200, and $400 \mathrm{mg} / \mathrm{kg}$ doses decreased nociception during the 2nd stage of the formalin test by $77.5,79.7$, and $91.3 \%$, respectively. The suppression of the pain in the second phase of the formalin assay indicated an antihyperalgesic and peripheric effect, demonstrating an anti-inflammatory effect [58].

In a comparative study using cultivated and wild $A$. cearensis species, the administration of $100-400 \mathrm{mg} / \mathrm{kg}$ of the ethanolic extract from specimens with 4,7 , or 9 months of cultivation presented antinociceptive activity, inhibiting both stages of the formalin test in mice by 32 to $64 \%$. Similar results were observed for the bark ethanolic extract of wild species. Both extracts also reduced carrageenan-induced paw edema $(\mathrm{Cg})$ at the $100-400 \mathrm{mg} / \mathrm{kg}$ concentrations [35]. Lima et al. [59] also demonstrated the antiedematogenic effects of the $A$. cearensis seed aqueous extract, where concentrations of 10 and $20 \%$ weight/volume significantly reduced carrageenan-induced paw edema in rats, with effects starting $2 \mathrm{~h}$ after administration of the phlogistic agent. A number of constituents isolated from $A$. cearensis also had their effects evaluated, where coumarin was one of these constituents, which at concentrations of $5-20 \mathrm{mg} / \mathrm{kg}$, reduced, in a dose-dependent manner, the nociception produced by acetic acid and formalin [52].

Leal et al. [54] also demonstrated the antinociceptive effects of coumarin (1) in the inhibition of contortions induced by acetic acid and the formalin test at the 5, 10, and $20 \mathrm{mg} / \mathrm{kg}$ concentrations. The 10 and $20 \mathrm{mg} / \mathrm{kg}$ concentrations also inhibited carrageenaninduced paw edema in a similar manner to the aforementioned study. In the study by Leal et al. [54], orally administered coumarin (1) (20 and $40 \mathrm{mg} / \mathrm{kg})$ significantly inhibited leukocyte and neutrophil migration in the peritoneal cavity of rats. Moreover, as demonstrated by Marinho et al. [55], coumarin (1) (10 and $20 \mathrm{mg} / \mathrm{mL})$ reduced paw edema in animals sensitized with ovalbumin and challenged with the antigen, where coumarin, at the stated doses, induced the inhibition of anti-ovalbumin antibody titers in a similar way to dexamethasone.

Animals pretreated with amburoside A (2) $(25$ and $50 \mathrm{mg} / \mathrm{kg}$ ) or isokaempferide (3) $(12.5,25$, and $50 \mathrm{mg} / \mathrm{kg})$ showed significant inhibition of the carrageenan-induced paw edema, where leukocyte and neutrophil migration in the peritoneal cavity of mice after the injection of carrageenan were also inhibited by the compounds [60]. The biflavonoids amburanin A and amburanin B (4-5) inhibited neutrophil degranulation by $92 \%$ and reduced human myeloperoxidase (MPO) activity by up to $53 \%$ when tested at the 25,50 , and $100 \mu \mathrm{g} / \mathrm{mL}$ concentrations [61].

The administration of vanillic acid (6) at the concentrations of 25 and $50 \mathrm{mg} / \mathrm{kg}$ showed antinociceptive effects by significantly reducing the two phases of the formalin test. In addition, the compound inhibited paw edema at the 25 and $50 \mathrm{mg} / \mathrm{kg}$ concentrations and leukocyte migration in the rat peritoneal cavity induced by carrageenan at the $50 \mathrm{mg} / \mathrm{kg}$ concentration [35]. The afrormosin (7) isoflavone inhibited the degranulation of the neutrophils stimulated by N-formyl-methionyl-leucyl-phenylalanine (fMLP) or phorbol 12-myristate-13-acetate (PMA), with $\mathrm{LC}_{50}$ values of $66.70 \mu \mathrm{M}$ and $0.374 \mu \mathrm{M}$, respectively. The 3.35 and $167.6 \mu \mathrm{M}$ concentrations inhibited myeloperoxidase activity by 39 and $76 \%$, 
respectively. Cellular treatment with afrormosin at $16.76-335.2 \mu \mathrm{M}$ concentrations reduced TNF- $\alpha$ release by $44 \%$ [62].

\subsubsection{Myorelaxant Activity}

The $A$. cearensis bark hydroalcoholic extract caused concentration-dependent relaxations in the trachea of guinea pigs pretreated with $0.3 \mu \mathrm{M}$ carbacol, obtaining an $\mathrm{EC}_{50}$ value of $3.64 \pm 0.4 \mathrm{mg} / \mathrm{mL}$ [54]. In the study by Leal et al. [56] the same extract evoked a concentration dependent relaxation in guinea pig trachea with an $\mathrm{IC}_{50}$ value of $3.16 \pm 0.55 \mathrm{mg} / \mathrm{mL}$ in the presence of three antagonists.

Studies also revealed the coumarin (1) myorelaxant activity in the trachea of guinea pigs pre-contracted with $0.3 \mu \mathrm{M}$ carbacol, which obtained an $\mathrm{EC}_{50}$ value of $0.08 \pm 0.01 \mathrm{mg} / \mathrm{mL}$ [54]. Similar results were observed by Leal et al. [56], where coumarin (1) showed a myorelaxing effect in guinea pig trachea pre-contracted with carbacol $(0.3 \mu \mathrm{M})$, histamine $(0.1 \mu \mathrm{M})$, or $\mathrm{KCl}(0.1 \mathrm{M})$, obtaining $\mathrm{IC}_{50}$ values of $0.045 \pm 0.013,0.084 \pm 0.016$, and $0.087 \pm 0.006 \mathrm{mg} / \mathrm{mL}$. These studies demonstrated the interaction of isolated compounds such as the coumarins and isokaempferol present in A. cearensis extracts, possibly conferring a myorelaxing effect to this plant.

\subsubsection{Antioxidant Activity}

The leaf ethanolic extract as well as the ethyl acetate and methanolic fractions, showed antioxidant activity when evaluated by the DPPH assay at the $0.1 \mathrm{mg} / \mathrm{mL}$ concentration, with an antioxidant potential of $93.63,83.21$ and $93.01 \%$, respectively. The bark ethanolic extract, on the other hand, presented an antioxidant potential of $94.55 \%$ at the $1 \mathrm{mg} / \mathrm{mL}$ concentration [50]. Antioxidant activity for the seed ethanolic extract at 30, 60, and $120 \mu \mathrm{g} / \mathrm{mL}$ concentrations with an $\mathrm{IC}_{50}$ value of $17.95 \mu \mathrm{g} / \mathrm{mL}$ was also observed [38].

Lopes et al. [62] evaluated the inhibitory effect of afrormosin (7) on the superoxide anion production and the total generation of reactive oxygen species (ROS) in human neutrophils stimulated by phorbol 12-myristate-13-acetate (PMA) using lucigeninenhanced chemiluminescence assays (LucCL) and luminol (LumCL). The results showed the isoflavone-inhibited ROS production with a significantly higher inhibitory effect in the LumCL $\left(\mathrm{IC}_{50}=19.09 \mu \mathrm{g} / \mathrm{mL}\right)$ than in the LucCL $\left(\mathrm{IC}_{50}>100 \mu \mathrm{g} / \mathrm{mL}\right)$ assay.

Antioxidative agents have a role in inhibiting oxidative stress that is induced due to free radicals, protecting the cells. Medicinal plants present a huge variety of compounds with antioxidative properties, with this effect being mediated by different mechanisms [63]. The antioxidant potential of the Fabaceae family has been demonstrated by several studies, most of which have been associated with the occurrence of flavonoids and highlighting the isoflavone class, which are considered to be the most bioavailable flavonoids and are restricted to some legume subfamilies [51].

\subsubsection{Neuroprotective Activity}

Several studies have shown evidence that natural products can reduce neuronal damage, making them a possible source for the development of new drugs and therapeutic strategies for the treatment of these diseases [64]. The dry extract, phenol fraction and amburoside A (2), obtained from A. cearensis demonstrated neuroprotection over microglial cells at the $5-200 \mathrm{mg} / \mathrm{mL}$ concentration [65]. The ethanolic, hexane, dichloromethane, and ethyl acetate extracts obtained from $A$. cearensis seeds presented a neuroprotective potential over PC12 neural cells exposed to glutamate-induced neuronal damage $(1 \mathrm{mM})$ at concentrations of $0.1-1000 \mu \mathrm{g} / \mathrm{mL}$ [39]. The ethanol and dichloromethane extracts from the seeds also demonstrated the neuroprotective effects against the neural damage induced by glutamate in rat cerebellar cultures at a concentration of $0.1 \mu \mathrm{g} / \mathrm{mL}$, with this effect being possibly associated with the increased expression of the astrocytic enzyme glutamine synthetase from the glial fibrillary acidic protein (GFAP) and $\beta$-III tubulin, indicating glial and neuronal preservation, respectively [40]. 
The neuroprotective effects observed are possibly due to the metabolites present in $A$. cearensis with antioxidant and anti-inflammatory properties that are able to regulate the intracellular signaling cascades of glutamate excitotoxicity, which is a critical component in the development of neurological and neurodegenerative diseases, and this regulation may minimize the main causes of neuronal death [40].

\subsubsection{Cytotoxic and Antiproliferative Activities}

The $A$. cearensis stem powder hydroalcoholic extract presented cytotoxicity in L929 fibroblasts and human keratinocytes (HaCaT) at the 31.25, 62.5, 125, 250, 500, and $1000 \mu \mathrm{g} / \mathrm{mL}$ concentrations. The same concentrations also demonstrated antiproliferative activity in human breast adenocarcinoma cell lines (MDA-MB-231 and MCF7) and mouse mammary gland tumors (4T1) [66]. At a concentration of $1000 \mu \mathrm{g} / \mathrm{mL}$, seed hexanic extract reduced the viability of Wistar rat cerebellar cells by $30 \%$ [40].

The compounds kaempferol (9), isokaempferide (3), amburoside A (2), and protocatechuic acid (8) showed cytotoxic activity against five tumor cell lines: B-16 cells (murine skin cancer), HCT-8 (human colon cancer), and MCF-7 (breast cancer human) as well as the EMC and HL-60 (leukemia cancer) cell lines from tumor cells. Isokaempferide obtained $\mathrm{IC}_{50}$ values of $2.6 \mu \mathrm{g} / \mathrm{mL}, 3.0 \mu \mathrm{g} / \mathrm{mL}, 5.4 \mu \mathrm{g} / \mathrm{mL}, 5.5 \mu \mathrm{g} / \mathrm{mL}$, and $3.6 \mu \mathrm{g} / \mathrm{mL}$ for EMC, HL-60, HCT-8, MCF-7, and B-16, respectively. Meanwhile, the $\mathrm{IC}_{50}$ values for protocatechuic acid were $>25,20.7,>25,>25$, and $>25 \mu \mathrm{g} / \mathrm{mL}$ for EMC, HL-60, HCT-8, MCF-7, and B-16, respectively. Amburoside obtained an $\mathrm{IC}_{50}$ value $>25 \mu \mathrm{g} / \mathrm{mL}$ for all tested strains, while kaempferol obtained an $\mathrm{IC}_{50}$ of 13.4, 22.7, 15.2, 21.2, $11.5 \mu \mathrm{g} / \mathrm{mL}$ for the lines EMC, HL-60, HCT-8, MCF-7, and B-16, respectively [67]. Based on these facts, extracts and compounds from $A$. cearensis demonstrated activity against several cancer cell lines. However, the mechanisms involved in these activities were not elucidated, making more studies necessary.

\subsubsection{Allelopathic Activity}

Allelopathy is a defense mechanism observed on several organisms that are mainly present in plants and involves the production and liberation of bioactive compounds in the environment. On plants, these compounds affect the growth and the development of neighbouring plants [68]. Previous reports have demonstrated the allelopathic effects on the germination of Lactuca sativa seeds that have received aqueous and methanolic treatments at concentrations 5,10, and $15 \mathrm{~g} / \mathrm{L}$ and 1, 5, 10, and $15 \mathrm{~g} / \mathrm{L}$, respectively, of the $A$. cearensis ground seed. Both extracts also showed an allelopathic activity on the germination of Raphanus satious L. seeds treated with $15 \mathrm{~g} / \mathrm{L}$ of A. cearensis extract [69]. The leaf aqueous extract almost completely prevented the germination of Amaranthus deflexus at the 50 and $100 \mathrm{~g} / \mathrm{L}$ doses, with a 99.3 and $99.5 \%$ decrease in germination percentage and germination velocity index, respectively, at the highest concentration [70].

The seed hydroalcoholic extract prevented the germination of Cucumis melo L. seeds and the emergence of seedlings at the $1,0.5$, and $0.25 \%$ weight/volume concentrations. However, the leaf extract evaluated in the same study did not prevent seed germination, despite the seedlings presenting abnormalities that exceeded $25 \%$ at the highest concentration [71]. Similar results were observed in the study by Oliveira et al. [48], where the hexane and dichloromethane fractions of the seed extract affected the emergence and initial growth processes of Cucumis melo L. at 1 and $0.5 \%$ weight/volume concentrations.

The allelochemicals belong to several different classes of secondary metabollites, including phenols, benzoic acid, and derivates of cinnamic acid, terpenoids, glicosides, among others [72]. However, the inhibition of germination in both weed seedlings and in Amaranthus deflexus as well as in edible plants such as Lactuca sativa, Raphanus sativus and Cucumis melo indicates a possible non-biosselectivity, which could result in a threat to non-target organisms. Therefore, this highlights the need for studies to systematically determine the bioselectivity and biosafety of the allelochemicals present in $A$. cearensis, which will guide the use of this species in practical applications. 


\subsubsection{Other Bioactivities}

In addition to the aforementioned bioactivities, $A$. cearensis has other properties that have been described in the literature. According to the study carried out by Trevisan et al. (2003) [73], the ethanolic extract of the stem bark caused 100\% inhibition of acetylcholinesterase (AChE) enzyme activity at a concentration of $2.3 \mathrm{mg} / \mathrm{mL}$. Meanwhile the hydroalcoholic extract obtained from the stem powder caused $83 \%$ inhibition, with an $\mathrm{IC}_{50}$ value of $0.3789 \mathrm{mg} / \mathrm{mL}$ [66].

The $A$. cearensis leaf ethanolic extract at a concentration of $0.2 \mathrm{mg} / \mathrm{mL}$ increased the preservation of pre-antral goat follicles for up to $6 \mathrm{~h}[41,74]$. At a concentration of $0.1 \mathrm{mg} / \mathrm{mL}$, the same extract also had a significant effect on the survival and in vitro development of secondary follicles isolated from sheep (Ovis aries) [75]. Similar results were observed in the study by Menezes et al. [76], where the A. cearensis leaf ethanolic extract at a concentration of $0.2 \mathrm{mg} / \mathrm{mL}$ maintained follicular survival and DNA integrity in a similar manner to those observed for the minimum essential medium (MEM) over $24 \mathrm{~h}$.

The seed aqueous extract exhibited marked larvicidal activity against the Aedes aegypti mosquito, with an $\mathrm{LC}_{50}$ value of $8.10 \pm 0.27 \mathrm{mg} / \mathrm{mL}$ within $24 \mathrm{~h}$ of exposure [77]. The leaf and stem bark powder $(2 \mathrm{~g})$ presented repellent activity against the bean weevil Callosobruchus maculatus, obtaining repellency rates of $0.46 \pm 0.05$ and $0.42 \pm 0.04$, respectively [78]. In addition, the hexane fraction from the leaf ethanolic extract at a concentration of $25 \mathrm{mg} / \mathrm{mL}$ showed in vitro acaricidal activity against engorged Rhipicephalus (Boophilus) microplus females, reaching oviposition and hatching inhibition values of $52.7 \%$ and $39.0 \%$, respectively [79]. In the study by Lima et al. [59], the $A$. cearensis seed aqueous extract demonstrated mutagenic activity over Allium cepa at concentrations of 0.1 and $0.5 \mathrm{mg} / \mathrm{mL}$.

An in vitro photoprotective activity for the $A$. cearensis leaf ethanolic extract has also been described, with UVB radiation absorption efficiency at wavelengths being in the 280 to $320 \mathrm{~nm}$ region, with a sun protection factor (SPF) equal to 17.60 at a concentration of $0.2 \mathrm{mg} / \mathrm{mL}[80]$.

Coumarin (1), identified as 1,2 benzopyrone, isolated from $A$. cearensis seeds at concentrations of $25,50,100,250$, and $500 \mathrm{mg} / \mathrm{mL}$ showed antileishmanial activity against Leishmania chagasi promastigotes [81].

Treatment with amburoside A (2) at 25 and $50 \mathrm{mg} / \mathrm{kg}$ doses significantly inhibited the increase in aspartate aminotransferase (AST) and alanine aminotransferase (ALT) serum levels in animals poisoned by carbon tetrachloride $\left(\mathrm{CCl}_{4}\right)$. In liver tissues, the compound inhibited the formation of $\mathrm{CCl}_{4}$-induced thiobarbituric acid reactive substances (TBARS) at both doses, indicating a $\mathrm{CCl}_{4}$-induced lipid peroxidation blockade [82].

Although the extracts and phytocompounds isolated from A. cearensis present a wide range of therapeutic properties that have already supported by experimental results, some medicinal properties such as depurative, diuretic, antispasmodic, and antivenom reported for this species remain unexplored, highlighting important areas of research with the opportunity for chemical and biological exploration to carry out in vivo and in vitro assays as well as for the evaluation of the mechanisms of action of the crude extracts and isolated compounds. 
Table 2. Biological activities of Amburana cearensis.

\begin{tabular}{|c|c|c|c|c|}
\hline Activity Tested & Extract/Part & Model Used & Concentrations/Dosage & Citations \\
\hline \multirow[t]{8}{*}{ Antibacterial } & Ethanol/stem bark & $\begin{array}{c}\text { Staphylococcus epidermidis; Staphylococcus } \\
\text { aureus; Staphylococcus caprie; Staphylococcus } \\
\text { intermedius; Klebsiella spp.; Salmonella spp., } \\
\text { Pseudomonas aeruginosa; Escherichia coli; } \\
\text { Enterococcus faecalis; Rhodococcus equi; Listeria } \\
\text { spp.; Corynebacterium spp.; Aeromonas spp.; } \\
\text { Proteus spp.; Yersinia enterocolitica; } \\
\text { Streptococcus agalactiae; Streptococcus suis; } \\
\text { Nocardia spp.; Vibrio spp.; Micrococcus spp.; } \\
\text { Edwadisiella spp. }\end{array}$ & $\begin{array}{c}\text { MBC-125; 145.8; } \\
\text { 333.33; 31.25; 83.33; } \\
\text { 145.8; 166.7; 166.7; } \\
\text { 187.5; 187.5; } 125 ; 41.67 ; \\
\text { 62.5; } 281.3 ; 104.2 ; 250 ; \\
\text { 83.33; } 125 ; 31.25 ; 125 ; \\
\quad 62.5 \mu \mathrm{L} / \mathrm{mL} \\
\text { respectively }\end{array}$ & {$[44]$} \\
\hline & Ethanol/leaves & S. aureus 25,923 & $\mathrm{MIC}-512 \mu \mathrm{g} / \mathrm{mL}$ & [45] \\
\hline & Hydroalcoholic & Acinetobacter spp. & $\mathrm{MBC}-9.375 \mu \mathrm{g} / \mathrm{mL}$ & [46] \\
\hline & Ethanol & Enterobacter spp.; E. Coli; and Klebsiella spp. & $\begin{array}{l}\text { MBC }-390.6 ; 1.302 ; \text { and } \\
911.4 \mu \mathrm{g} / \mathrm{mL} \\
\text { respectively }\end{array}$ & [46] \\
\hline & Ethanol/stem bark & Staphylococcus spp. & $\mathrm{MBC}-12.500 \mu \mathrm{g} / \mathrm{mL}$ & [47] \\
\hline & Chloroform/stem bark & P. aeruginosa and Bacillus cereus & $\mathrm{MIC}-6900 \mu \mathrm{g} / \mathrm{mL}$ & [36] \\
\hline & Ethanol/seeds & $\begin{array}{l}\text { E. coli }(25,922) ; \text { S. aureus }(29,213) ; \text { P. aeruginosa } \\
(27,853) ; \text { L. monocytogenes }(35,152) ; \text { Shigella } \\
\text { flexneri }(700,930)\end{array}$ & $\begin{array}{l}\text { MIC: } 1000 ; 250 ; 250 \\
500 ; \text { and } 250 \mu \mathrm{g} / \mathrm{mL}, \\
\quad \text { respectively }\end{array}$ & [38] \\
\hline & $\begin{array}{c}\text { Crude and fractions } \\
\text { (ammonium sulfate } \\
\text { concentration: } 0-30 \% \text {, } \\
30-60 \% \text { and } \\
60-90 \% \text { / seeds }\end{array}$ & S. aureus (SA10) and E. coli (EC06) & $\mathrm{MIC} \geq 1024 \mu \mathrm{g} / \mathrm{mL}$ & [48] \\
\hline Antifungal & Proteic fractions/seeds & $\begin{array}{l}\text { Colletotrichum lindemuthianum; Fusarium } \\
\text { oxysporum; Fusarium solani; Candida albicans; } \\
\text { and Saccharomyces cerevisiae }\end{array}$ & $\begin{array}{l}\text { Filamentous fungi: } \\
160 \mu \mathrm{g} / \mathrm{mL} ; \\
\text { Yeasts: } 80 \text { and } \\
160 \mu \mathrm{g} / \mathrm{mL}\end{array}$ & {$[50]$} \\
\hline \multirow[t]{5}{*}{$\begin{array}{l}\text { Antinociceptive } \\
\text { and antiede- } \\
\text { matogenic }\end{array}$} & $\begin{array}{l}\text { Hydroalcoholic/ } \\
\text { stem bark }\end{array}$ & Swiss mice and Wistar rats & 100 and $200 \mathrm{mg} / \mathrm{kg}$ & [52] \\
\hline & $\begin{array}{l}\text { Hydroalcoholic/ } \\
\text { stem bark }\end{array}$ & Swiss mice and Wistar rats & $\begin{array}{l}100 \text { and } 200 \mathrm{mg} / \mathrm{kg} \text {, } \\
\text { respectively }\end{array}$ & [54] \\
\hline & $\begin{array}{l}\text { Hydroalcoholic/ } \\
\text { stem bark }\end{array}$ & Mice BALB/c & $\begin{array}{c}200 \mathrm{mg} / \mathrm{kg} \text { and } \\
400 \mathrm{mg} / \mathrm{kg}\end{array}$ & [55] \\
\hline & Ethanol/stem bark & Swiss mice and Wistar rats & $100 ; 200$ and $400 \mathrm{mg} / \mathrm{kg}$ & {$[57]$} \\
\hline & Aqueous/seeds & Rattus norvegicus & 10 and $20 \% w / v$ & [59] \\
\hline $\begin{array}{c}\text { Anti- } \\
\text { inflammatory }\end{array}$ & $\begin{array}{l}\text { Hydroalcoholic/ } \\
\text { stem bark }\end{array}$ & Wistar rats & 200 and $400 \mathrm{mg} / \mathrm{kg}$ & [56] \\
\hline \multirow[t]{2}{*}{ Myorelaxant } & $\begin{array}{l}\text { Hydroalcoholic/ } \\
\text { stem bark }\end{array}$ & Guinea-pig isolated trachea & $\begin{array}{c}\mathrm{EC}_{50}: \\
3.64 \pm 0.4 \mathrm{mg} / \mathrm{mL}\end{array}$ & [54] \\
\hline & $\begin{array}{l}\text { Hydroalcoholic/ } \\
\text { stem bark }\end{array}$ & Guinea-pig isolated trachea & $\begin{array}{c}\mathrm{IC}_{50} \\
3.16 \pm 0.55 \mathrm{mg} / \mathrm{mL}\end{array}$ & [56] \\
\hline Antioxidant & $\begin{array}{l}\text { Ethanol/leaves and } \\
\text { bark. Methanol and } \\
\text { ethyl acetate } \\
\text { fractions/leaves }\end{array}$ & DPPH & 0.1 and $1 \mathrm{mg} / \mathrm{mL}$ & {$[50]$} \\
\hline
\end{tabular}


Table 2. Cont.

\begin{tabular}{|c|c|c|c|c|}
\hline Activity Tested & Extract/Part & Model Used & Concentrations/Dosage & Citations \\
\hline & Ethanol/seeds & DPPH & $\mathrm{IC}_{50} 17.95 \mu \mathrm{g} / \mathrm{mL}$ & [38] \\
\hline \multirow[t]{3}{*}{ Neuroprotective } & $\begin{array}{l}\text { Ethanolic, hexane, } \\
\text { dichloromethane, and } \\
\text { ethyl acetate/seeds }\end{array}$ & Neural PC12 cells & $0.1-1000 \mu \mathrm{g} / \mathrm{mL}$ & [39] \\
\hline & $\begin{array}{c}\text { Ethanol and } \\
\text { dichloromethane/seeds }\end{array}$ & Cerebellar cells of wistar rats & $0.1 \mu \mathrm{g} / \mathrm{mL}$ & [40] \\
\hline & $\begin{array}{l}\text { Dry extract and phenol } \\
\text { fraction }\end{array}$ & Microglial cells & $5-200 \mathrm{mg} / \mathrm{mL}$ & {$[65]$} \\
\hline \multirow[t]{2}{*}{ Antiproliferative } & $\begin{array}{l}\text { Hydroalcoholic/stem } \\
\text { powder }\end{array}$ & HaCaT; MDA-MB-231 and MCF7; $4 \mathrm{~T} 1$ & $\begin{array}{c}31.25 ; 62.5 ; 125 ; 250 ; \\
500 ; \text { and } 1000 \mu \mathrm{g} / \mathrm{mL}\end{array}$ & [66] \\
\hline & Hexane/seeds & Cerebellar cells of Wistar rats & $1000 \mu \mathrm{g} / \mathrm{mL}$ & [40] \\
\hline \multirow[t]{6}{*}{ Allelopathic } & $\begin{array}{c}\text { Aqueous and } \\
\text { metanol/seeds }\end{array}$ & Lactuca sativa & $\begin{array}{l}5,10, \text { and } 15 \mathrm{~g} ; 1 ; 5 ; 10 ; \\
\text { and } 15 \mathrm{~g} \text {, respectively }\end{array}$ & [69] \\
\hline & $\begin{array}{c}\text { Aqueous and } \\
\text { methanol/seeds }\end{array}$ & Raphanus sativus L. & $15 \mathrm{~g}$ & [69] \\
\hline & $\begin{array}{c}\text { Aqueous } \\
\text { extract/leaves }\end{array}$ & Amaranthus deflexus & 50 and $100 \mathrm{~g} / \mathrm{L}$ & [70] \\
\hline & $\begin{array}{c}\text { Hydroalcoholic } \\
\text { extract/seeds }\end{array}$ & Cucumis melo L. & $1 ; 0.5 ;$ and $0.25 \% w / v$ & [71] \\
\hline & Hydroalcoholic/leaves & Cucumis melo L. & $1 ; 0.5 ;$ and $0.25 \% w / v$ & [71] \\
\hline & $\begin{array}{c}\text { Hexane and } \\
\text { dichloromethane } \\
\text { fracionas / seeds }\end{array}$ & Cucumis melo $\mathrm{L}$. & 1 and $0.5 \% w / v$ & [48] \\
\hline \multirow[t]{3}{*}{$\begin{array}{l}\text { Survival of } \\
\text { preantral } \\
\text { follicles }\end{array}$} & Ethanol/leaves & Ovarian cortical tissues goats & $0.2 \mathrm{mg} / \mathrm{ml}$ & [41] \\
\hline & Ethanol/leaves & Ovarian cortical tissues ovine (Ovis aries) & $0.1 \mathrm{mg} / \mathrm{mL}$ & [75] \\
\hline & Ethanol/leaves & Ovarian cortical tissues ovine & $0.2 \mathrm{mg} / \mathrm{mL}$ & [76] \\
\hline Larvicidal & Aqueous/seeds & Aedes aegypti & $\begin{array}{c}\mathrm{LC}_{50} 8.10 \pm 0.27 \\
\mathrm{mg} / \mathrm{mL} \text { after } 24 \mathrm{~h} \text { of } \\
\text { exposure }\end{array}$ & [77] \\
\hline Repellency & $\begin{array}{c}\text { Powder/leaves and } \\
\text { bark }\end{array}$ & Callosobruchus maculatus & $2 \mathrm{~g}$ & [78] \\
\hline Acaricidal & Hexane fraction/leaves & Rhipicephalus (Boophilus) microplus & $25 \mathrm{mg} / \mathrm{mL}$ & [79] \\
\hline Mutagenic & Aqueous/seeds & Meristematic cells of Allium cepa & $\begin{array}{c}0.1 \mathrm{mg} / \mathrm{mL} \text { and } 0.5 \\
\mathrm{mg} / \mathrm{mL}\end{array}$ & [59] \\
\hline Photoprotective & Ethanol/leaves & - & $\mathrm{SPF}=17.60$ & [80] \\
\hline
\end{tabular}

HaCaT: human keratinocytes; MDA-MB-231 and MCF7: human breast adenocarcinoma; 4T1: Mouse tumor mammary gland; MIC: minimum inhibitory concentration; $\mathrm{MBC}$ : minimum bactericidal concentration; $\mathrm{LC}_{50}$ : median lethal concentration; DPPH: 2,2-Diphenyl-1-picrylhydrazyl radical; SPF: protection factor. 
Table 3. Biological activities of compounds isolated from A. cearensis.

\begin{tabular}{|c|c|c|c|c|}
\hline Phytochemicals & Activity Tested & Model Used & $\begin{array}{l}\text { Concentraction } \\
\text { /Dosage }\end{array}$ & Citations \\
\hline Coumarin (1) & $\begin{array}{l}\text { Antinociceptive and } \\
\text { antiedematogenic }\end{array}$ & Swiss mice and Wistar rats & $5-20 \mathrm{mg} / \mathrm{kg}$ and $10 \mathrm{mg} / \mathrm{kg}$ & [52] \\
\hline Coumarin (1) & $\begin{array}{l}\text { Anti-inflammatory, } \\
\text { antinociceptive }\end{array}$ & Swiss mice and Wistar rats & $5 ; 10 ;$ and $20 \mathrm{mg} / \mathrm{kg}$ & [54] \\
\hline Coumarin (1) & Anti-inflammatory & Wistar rats & 20 and $40 \mathrm{mg} / \mathrm{kg}$ & [54] \\
\hline Coumarin (1) & $\begin{array}{l}\text { Anti-inflammatory and } \\
\text { antiedematogenic }\end{array}$ & $\mathrm{BALB} / \mathrm{c}$ mice & 10 and $20 \mathrm{mg} / \mathrm{mL}$ & {$[55]$} \\
\hline Coumarin (1) & Myorelaxant & Guinea pig trachea & $\mathrm{EC}_{50} 0.08 \pm 0.01 \mathrm{mg} / \mathrm{mL}$ & [54] \\
\hline Coumarin (1) & Myorelaxant & Guinea pig trachea & $\begin{array}{c}\mathrm{IC}_{50} 0.045 \pm 0.013 ; 0.084 \pm 0.016 \\
\text { and } 0.087 \pm 0.006 \mathrm{mg} / \mathrm{mL} \\
\text { (carbachol, histamine and } \mathrm{KCl} \text { ) }\end{array}$ & [56] \\
\hline Coumarin (1) & Antileishmanial & $\begin{array}{l}\text { Leishmania chagasi } \\
\text { (promastigotes) }\end{array}$ & $25 ; 50 ; 100 ; 250 ;$ and $500 \mathrm{mg} / \mathrm{mL}$ & [81] \\
\hline Amburoside A (2) & $\begin{array}{l}\text { Antiedematogenic and } \\
\text { anti-inflammatory }\end{array}$ & Swiss mice and Wistar rats & 25 and $50 \mathrm{mg} / \mathrm{kg}$ & {$[60]$} \\
\hline Amburoside A (2) & Neuroprotective & Rat microglial cell cultures & $5-200 \mathrm{mg} / \mathrm{mL}$ & [65] \\
\hline Amburoside A (2) & Hepatoprotective & $\begin{array}{l}\mathrm{CCl}_{4} \text {-induced } \\
\text { hepatotoxicity in } \\
\text { Wistar rats }\end{array}$ & 25 and $50 \mathrm{mg} / \mathrm{kg}$ & [82] \\
\hline Isokaempferide (3) & Cytotoxic & $\begin{array}{l}\text { CEM; HL-60; HCT-8; } \\
\text { MCF-7 and B-16 }\end{array}$ & $\begin{array}{c}\mathrm{IC}_{50}: 2.6 \mu \mathrm{g} / \mathrm{mL}(\mathrm{CEM}) \\
3.0 \mu \mathrm{g} / \mathrm{mL}(\mathrm{HL}-60) ; 5.4 \mu \mathrm{g} / \mathrm{mL} \\
(\mathrm{HCT}-8) ; 5.5 \mu \mathrm{g} / \mathrm{mL}(\mathrm{MCF}-7) ; \text { and } \\
3.6 \mu \mathrm{g} / \mathrm{mL} \text { (B-16) }\end{array}$ & [67] \\
\hline $\begin{array}{l}\text { Amburanins A and B } \\
\text { (4 and 5) }\end{array}$ & Anti-inflammatory & Human neutrophils & $25 ; 50$ and $100 \mu \mathrm{g} / \mathrm{mL}$ & [61] \\
\hline Vanillic acid (6) & $\begin{array}{c}\text { Antinociceptive, } \\
\text { antiedematogenic and } \\
\text { anti-inflammatory }\end{array}$ & Swiss mice and Wistar rats & 25 and $50 \mathrm{mg} / \mathrm{kg}$ & {$[35]$} \\
\hline Afrormosin (7) & Anti-inflammatory & $\begin{array}{l}\text { Human neutrophils } \\
\text { stimulated by } \\
\text { fMLP or PMA }\end{array}$ & $\begin{array}{c}\mathrm{IC}_{50} 66.70 \mu \mathrm{M} \text { (fMLP) and } \\
0.374 \mu \mathrm{M} \text { (PMA); } \\
\text { 3.35-167.6 } \mu \mathrm{M} \text { (inhibition of MPO); } \\
\text { 16.76-335.2 } \mu \mathrm{M} \text { (reduced } \\
\text { TNF-a level) }\end{array}$ & {$[62]$} \\
\hline Afrormosin (7) & Antioxidant & $\begin{array}{l}\text { Human neutrophils } \\
\text { (chemiluminescent } \\
\text { Probes-luminol } \\
\text { and lucigenin }\end{array}$ & $\begin{array}{l}\mathrm{CL}_{50:} \text { Lucigenin }(>100 \mu \mathrm{g} / \mathrm{mL}) \\
\text { and luminol }(19.09 \mu \mathrm{g} / \mathrm{mL})\end{array}$ & [62] \\
\hline Protecatechuic acid (8) & Cytotoxic & $\begin{array}{l}\text { CEM; HL-60; HCT-8; } \\
\text { MCF-7; and B-16 }\end{array}$ & $\begin{array}{c}\mathrm{IC}_{50}:>25.0 \text { (CEM); } 20.7 \text { (HL-60); } \\
>25.0(\mathrm{HCT}-8) ;>25.0 \text { (MCF-7); } \\
>25.0 \mu \mathrm{g} / \mathrm{mL}(\mathrm{B}-16)\end{array}$ & [67] \\
\hline Kaempferol (9) & Cytotoxic & $\begin{array}{l}\text { CEM; HL-60; HCT-8; } \\
\text { MCF-7; and B-16 }\end{array}$ & $\begin{array}{c}\mathrm{IC}_{50} 13.4 \mu \mathrm{g} / \mathrm{mL}(\mathrm{CEM}) \\
22.7 \mu \mathrm{g} / \mathrm{mL}(\mathrm{HL}-60) ; 15.2 \mu \mathrm{g} / \mathrm{mL} \\
(\mathrm{HCT}-8) ; 21.2 \mu \mathrm{g} / \mathrm{mL}(\mathrm{MCF}-7) \\
11.5 \mu \mathrm{g} / \mathrm{mL}(\mathrm{B}-16)\end{array}$ & {$[67]$} \\
\hline
\end{tabular}


Table 3. Cont.

\begin{tabular}{cccc}
\hline Phytochemicals & Activity Tested & Model Used & $\begin{array}{c}\text { Concentraction } \\
\text { /Dosage }\end{array}$ \\
\hline 2-methoxy-4- & Antibacterial & $\begin{array}{c}\text { Salmonella entérica; E. Coli; } \\
\text { P. Aeruginosa; B. Cereus; L. } \\
\text { Monocytogenes, S. Aureus } \\
\text { and K. Pneumoniae }\end{array}$ & $\begin{array}{c}\text { MIC-215; 215; 431; 431; 215; 215; } \\
\text { and 215 } \mu \mathrm{g} / \mathrm{mL}, \text { respectively }\end{array}$ \\
\hline
\end{tabular}

$\mathrm{EC}_{50}$ : half maximal efective concentration; $\mathrm{IC}_{50}$ : half maximal inhibitory concentration; $\mathrm{CL}_{50}$ : median lethal concentration; B-16 (murine skin cancer); HCT-8 (human colon cancer); MCF-7 (human breast cancer); CEM and HL-60 (leukemia cancer); MPO: mieloperoxidase; fMLP: formyl-methionyl-leucyl-phenylalanine; PMA: phorbol-12-myristate-13-acetate; TNF- $\alpha$ : tumor necrosis factor alpha.

\section{Conclusions}

Phytochemical, ethnobiological, and pharmacological studies of Amburana cearensis are well reported. Many of these activitites were elucidated based on studies with different extracts and phytocompounds that had been isolated, with its traditional usages being supported by these bioactivities. For example, all of the antibacterial, antifungal, antiinflammatory, antinociceptive, antioxidant, and myorelaxant activities studied can be directly associated with traditional usages against infections caused by bacteria and fungi, against respiratory and gastrointestinal illnesses, fever, malaria, among others. New biological activities such as acaricidal, larvicide, repellent, photoprotective, antileishmanial, activities were observed, among others. However, there are some activities that are unable to be associated with traditional usage, as depurative, diuretic, antispasmodic, antivenom, activities, among others. The extensive use of this plant suggests relative security against acute toxicity. More studies determining the general toxicity of this plant are necessary.

Author Contributions: Conceptualization, F.A.B.d.C. and H.D.M.C.; methodology, Z.d.S.S. and S.R.B.; writing-original draft preparation, Z.d.S.S., V.d.Q.B., B.K. and A.S.; writing-review and editing, F.A.B.d.C., N.S.M. and H.D.M.C.; supervision, F.A.B.d.C., V.d.Q.B. and H.D.M.C.; Funding acquisition: B.K., Z.S. and A.S. All authors have read and agreed to the published version of the manuscript.

Funding: This study was funded by the Fundação Cearense de Apoio ao Desenvolvimento Científico e Tecnológico-FUNCAP (BPI 02/2020 (no. BP4-0172-00168.01.00/20 SPU (no. 09673071/2020); Coordenação de Aperfeiçoamento de Pessoal de Nível Superior-CAPES, Basic Science Research Program through the National Research Foundation of Korea (NRF) funded by the Ministry of Education (NRF-2020R1I1A2066868), the National Research Foundation of Korea (NRF) grant funded by the Korean government (MSIT) (No. 2020R1A5A2019413), a grant from the Korea Health Technology R\&D Project through the Korea Health Industry Development Institute (KHIDI), funded by the Ministry of Health \& Welfare, Republic of Korea (grant number: HF20C0116), and a grant of the Korea Health Technology R\&D Project through the Korea Health Industry Development Institute (KHIDI), funded by the Ministry of Health \& Welfare, Republic of Korea (grant number: HF20C0038).

Institutional Review Board Statement: Not applicable.

Informed Consent Statement: Not applicable.

Data Availability Statement: Not applicable.

Conflicts of Interest: The authors declare that there are no conflicts of interest.

Sample Availability: Samples of the compounds are not available from the authors.

\section{References}

1. Fierascu, R.C.; Fierascu, I.; Ortan, A.; Georgiev, M.I.; Sieniawska, E. Innovative Approaches for Recovery of Phytoconstituents from Medicinal/Aromatic Plants and Biotechnological Production. Molecules 2020, 25, 309. [CrossRef] [PubMed]

2. World Health Organization (WHO). Traditional Medicine Strategy: 2014-2023. 2014. Available online: https://www.who.int/ publications/i/item/9789241506096 (accessed on 15 March 2020). 
3. Newman, D.J.; Cragg, G.M. Natural Products as Sources of New Drugs over the 30 Years from 1981 to 2010. J. Nat. Prod. 2012, 75, 311-335. [CrossRef]

4. Gao, T.; Yao, H.; Song, J.; Liu, C.; Zhu, Y.; Ma, X.; Pang, X.; Xu, H.; Chen, S. Identification of medicinal plants in the family Fabaceae using a potential DNA barcode ITS2. J. Ethnopharmacol. 2010, 130, 116-121. [CrossRef] [PubMed]

5. Dzoyem, J.P.; McGaw, L.J.; Eloff, J.N. In vitro antibacterial, antioxidant and cytotoxic activity of acetone leaf extracts of nine under-investigated Fabaceae tree species leads to potentially useful extracts in animal health and productivity. BMC Complement. Altern. Med. 2014, 14, 147. [CrossRef] [PubMed]

6. Seleme, L.G.P.; Stirton, C.H.; Sartori, Â.L.B.; Mansano, V.F. A taxonomic review and a new species of the south american woody genus amburana (leguminosae, papilionoideae). Phytotaxa 2015, 212, 249. [CrossRef]

7. Bitu, V.D.C.N.; Bitu, V.D.C.N.; Matias, E.F.F.; de Lima, W.P.; Portelo, A.D.C.; Coutinho, H.; de Menezes, I.R.A. Ethnopharmacological study of plants sold for therapeutic purposes in public markets in Northeast Brazil. J. Ethnopharmacol. 2015, 172, 265-272. [CrossRef]

8. Macedo, J.G.F.; de Menezes, I.R.A.; Ribeiro, D.A.; de Oliveira Santos, M.; de Mâcedo, D.G.; Macêdo, M.J.F.; de Almeida, B.V.; de Oliveira, L.G.S.; Leite, C.P.; Souza, M.M.D.A. Analysis of the Variability of Therapeutic Indications of Medicinal Species in the Northeast of Brazil: Comparative Study. Evid.-Based Complementary Altern. Med. 2018, 2018, 1-28. [CrossRef] [PubMed]

9. Leite, E.J. State-of-knowledge on Amburana cearensis (Fr. Allem.) A.C. Smith (Leguminosae: Papilionoideae) for genetic conservation in Brazil. J. Nat. Conserv. 2005, 13, 49-65. [CrossRef]

10. Leite, V.G.; Teixeira, S.P.; Mansano, V.F.; Prenner, G. Floral Development of the Early-Branching Papilionoid Legume Amburana cearensis (Leguminosae) Reveals Rare and Novel Characters. Int. J. Plant Sci. 2015, 176, 94-106. [CrossRef]

11. Da Silva, G.L.; Filho, S.M.; Zandavalli, R.B.; Pereira, D.D.S.; De Sousa, G.G. Biometria e emergência de Amburana cearensis (Allemão) A.C. Smith em função da coloração do fruto. Ciência Florestal 2013, 23, 635-642. [CrossRef]

12. Cardoso, D.; São-Mateus, W.M.; da Cruz, D.T.; Zartman, C.E.; Komura, D.L.; Kite, G.; Prenner, G.; Wieringa, J.J.; Clark, A.; Lewis, G.; et al. Filling in the gaps of the papilionoid legume phylogeny: The enigmatic Amazonian genus Petaladenium is a new branch of the early-diverging Amburaneae clade. Mol. Phylogenetics Evol. 2015, 84, 112-124. [CrossRef]

13. Loureiro, M.B.; Teles, C.A.S.; Virgens, I.O.; De Araújo, B.R.N.; Fernandez, L.G.; De Castro, R.D. Aspectos morfoanatômicos e fisiológicos de sementes e plântulas de Amburana cearensis (Fr. All.) A.C. Smith (Leguminosae-Papilionoideae). Revista Árvore 2013, 37, 679-689. [CrossRef]

14. Cunha, M.D.C.L.; Ferreira, R.A. Aspectos morfológicos da semente e do desenvolvimento da planta jovem de Amburana cearensis (Arr. Cam.) A.C. Smith-Cumaru-Leguminosae Papilionoideae. Rev. Bras. Sement 2003, 25, 89-96. [CrossRef]

15. Ebrahimi, F.; Torbati, M.; Mahmoudi, J.; Valizadeh, H. Medicinal Plants as Potential Hemostatic Agents. J. Pharm. Pharm. Sci. 2020, 23, 10-23. [CrossRef]

16. Hajdu, Z.; Hohmann, J. An ethnopharmacological survey of the traditional medicine utilized in the community of Porvenir, Bajo Paraguá Indian Reservation, Bolivia. J. Ethnopharmacol. 2012, 139, 838-857. [CrossRef]

17. De Morais, S.M.; Dantas, J.D.P.; Da Silva, A.R.A.; Magalhães, E.F. Plantas medicinais usadas pelos índios Tapebas do Ceará. Rev. Bras. Farm. 2005, 15, 169-177. [CrossRef]

18. Barboza Da Silva, N.C.; Delfino Regis, A.C.; Esquibel, M.A.; Santos, S.; do Espirito, J.; de Almeida, M.Z. Medicinal plants use in Barra II quilombola community-Bahia, Brazil. Bol. Latinoam. Caribe Plantas Med. Aromat. 2012, 11, $435-453$.

19. Bravo, J.A.; Sauvain, M.G.; Gimenez, A.T.; Muñoz, V.O.; Callapa, J.; Men-Olivier, L.L.; Massiot, G.; Lavaud, C. Bioactive phenolic glycosides from Amburana cearensis. Phytochemistry 1999, 50, 71-74. [CrossRef]

20. Agra, M.; Baracho, G.; Nurit, K.; Basílio, I.; Coelho, V. Medicinal and poisonous diversity of the flora of "Cariri Paraibano", Brazil. J. Ethnopharmacol. 2007, 111, 383-395. [CrossRef]

21. Conceição, G.; Ruggieri, A.; Araujo, M.F.; Conceição, T.T.M.M.; Conceição, M.A.M.M. Plantas do cerrado: Comercialização, uso e indicação terapêutica fornecida pelos raizeiros e vendedores, Teresina, Piauí. Sci. Plena 2011, 7, 1-6.

22. Melo, C.A.; Souza, P.O.; Damasceno, E. atividade farmacológica da planta Amburana cearensis (imburana). Rev. Bras. Pesqui. em Ciências da Saúde 2014, 1, 26-29.

23. De Albuquerque, U.P.; de Medeiros, P.M.; de Almeida, A.L.S.; Monteiro, J.M.; Neto, E.M.D.F.L.; de Melo, J.G.; dos Santos, J.P. Medicinal plants of the caatinga (semiarid) vegetation of NE Brazil: A quantitative approach. J. Ethnopharmacol. 2007, 114, 325-354. [CrossRef] [PubMed]

24. Baptistel, A.; Coutinho, J.; Neto, E.L.; Monteiro, J. Plantas medicinais utilizadas na Comunidade Santo Antônio, Currais, Sul do Piauí: Um enfoque etnobotânico. Rev. Bras. Plantas Med. 2014, 16, 406-425. [CrossRef]

25. Cartaxo, S.L.; Souza, M.M.D.A.; de Albuquerque, U.P. Medicinal plants with bioprospecting potential used in semi-arid northeastern Brazil. J. Ethnopharmacol. 2010, 131, 326-342. [CrossRef] [PubMed]

26. Castro, K.N.C.; Wolschick, D.; Leite, R.R.S.; Andrade, I.M.; Magalhaões, J.A.; Mayo, S.J. Ethnobotanical and ethnoveterinary study of medicinal plants used in the municipality of Bom Princpio do Piau, Piau, Brazil. J. Med. Plants Res. 2016, 10, 318-330. [CrossRef]

27. Fagundes, N.C.A.; Oliveira, G.L.; De Souza, B.G. Etnobotânica de plantas medicinais utilizadas no distrito de Vista Alegre, Claro dos Poções-Minas Gerais. Rev. Fitos 2017, 11, 62-80. [CrossRef]

28. Paulino, R.D.C.; Henriques, G.P.D.S.A.; Moura, O.N.S.; Coelho, M.D.F.B.; Azevedo, R.A.B. Medicinal plants at the Sítio do Gois, Apodi, Rio Grande do Norte State, Brazil. Rev. Bras. Farm. 2012, 22, 29-39. [CrossRef] 
29. Pereira Júnior, R.L.; Andrade, A.P.; Araújo, K.D.; Barbosa, A.S.; Barbosa, F.M. Species as an Alternative to the Development of New Phytochemicals. Floresta e Ambient. 2014, 21, 509-520. [CrossRef]

30. Ribeiro, D.A.; de Oliveira, L.G.S.; de Macêdo, D.G.; de Menezes, I.R.A.; da Costa, J.G.M.; da Silva, M.A.P.; Lacerda, S.R.; Souza, M.M.D.A. Promising medicinal plants for bioprospection in a Cerrado area of Chapada do Araripe, Northeastern Brazil. J. Ethnopharmacol. 2014, 155, 1522-1533. [CrossRef]

31. Dias, D.A.; Urban, S.; Roessner, U. A Historical Overview of Natural Products in Drug Discovery. Metabolites 2012, 2, 303-336. [CrossRef]

32. Negri, G.; Oliveira, A.F.M.; Salatino, M.L.F.; Salatino, A. Chemistry of the stern bark of Amburana cearensis (Allemao) (AC SM.) Rev. Bras. Plantas Med. 2004, 6, 1-4.

33. Canuto, K.M.; Silveira, E.R. Constituintes químicos da casca do caule de Amburana cearensis A.C. Smith. Química Nova 2006, 29, 1241-1243. [CrossRef]

34. Canuto, K.M.; Lima, M.A.S.; Silveira, E.R. Amburosides C-H and 6-O-protocatechuoyl coumarin from Amburana cearensis. J. Braz. Chem. Soc. 2010, 21, 1746-1753. [CrossRef]

35. Leal, L.; Pierdoná, T.; Góes, J.; Fonsêca, K.; Canuto, K.; Silveira, E.; Bezerra, A.; Viana, G. A comparative chemical and pharmacological study of standardized extracts and vanillic acid from wild and cultivated Amburana cearensis A.C. Smith Phytomedicine 2011, 18, 230-233. [CrossRef] [PubMed]

36. Sá, M.B.; Ralph, M.T.; Nascimento, D.C.O.; Ramos, C.S.; Barbosa, I.M.S.; Sá, F.B.; Lima-Filho, J. Phytochemistry and Preliminary Assessment of the Antibacterial Activity of Chloroform Extract of Amburana cearensis (Allemão) A.C. Sm. Against Klebsiella pneumoniae Carbapenemase-Producing Strains. Evid.-Based Complement. Altern. Med. 2014, 2014, 786586. [CrossRef]

37. Costa, T.A.C.; Campos, V.P.; Menezes, J.S.; Oliva, S.T.; West, C.B. Phytochemical Profile of Seed Extracts of Plants Typical of the Brazilian Semiarid and their Potential Application in Brackish Water Desalination. J. Braz. Chem. Soc. 2016, 27, 1694-1703. [CrossRef]

38. Aguiar, A.A.; Soares, I.M.; Marson, P.G.; Bastos, E.G.P.; Ascêncio, S.D.; Aguiar, R.W.S. Development of a rich fraction in phenolic compounds with high antioxidant and antimicrobial activity in Amburana cearensis seeds extracts. J. Med. Plants Res. 2017, 11, 648-655. [CrossRef]

39. Pereira, E.P.; Braga-De-Souza, S.; Santos, C.C.; Santos, L.O.; Cerqueira, M.D.; Ribeiro, P.R.; Fernandez, L.G.; Silva, V.D.; Costa, S.L. Amburana cearensis seed extracts protect PC-12 cells against toxicity induced by glutamate. Rev. Bras. Farm. 2017, 27, 199-205. [CrossRef]

40. Pereira, L.E.P.; Souza, C.S.; Amparo, J.; Ferreira, R.S.; Nuñez-Figueredo, Y.; Fernandez, L.G.; Ribeiro, P.R.; Braga-de-Souza, S.; Amaral, V.D.S.; Costa, S.L. Amburana cearensis seed extract protects brain mitochondria from oxidative stress and cerebellar cells from excitotoxicity induced by glutamate. J. Ethnopharmacol. 2017, 209, 157-166. [CrossRef]

41. Gouveia, B.B.; Barros, V.R.P.; Gonçalves, R.J.S.; Barberino, R.S.; Menezes, V.G.; Lins, T.L.B.; Macedo, T.J.S.; Santos, J.M.S.; Rolim, L.A.; Almeida, J.R.G.S.; et al. Effect of ovarian tissue transportation in Amburana cearensis extract on the morphology and apoptosis of goat preantral follicles. Anim. Reprod. 2015, 12, 316-323.

42. De Oliveira, G.P.; da Silva, T.M.G.; Camara, C.A.; Santana, A.L.B.D.; Moreira, M.S.A.; Silva, T.M.S. Isolation and structure elucidation of flavonoids from Amburana cearensis resin and identification of human DNA topoisomerase II- $\alpha$ inhibitors. Phytochem. Lett. 2017, 22, 61-70. [CrossRef]

43. Canuto, K.M.; Silveira, E.R.; Bezerra, A.M.E. Estudo fitoquímico de espécimens cultivados de cumaru (Amburana cearensis A. C. Smith). Química Nova 2010, 33, 662-666. [CrossRef]

44. Sá, M.D.C.A.D.; Peixoto, R.D.M.; Krewer, C.D.C.; Almeida, J.R.G.D.S.; De Vargas, A.C.; Da Costa, M.M. Antimicrobial activity of caatinga biome ethanolic plant extracts against gram negative and positive bacteria. Rev. Bras. Ciência Veterinária 2011, $18,62-66$. [CrossRef]

45. Figueredo, F.G.; Ferreira, E.O.; Lucena, B.F.F.; Torres, C.M.G.; Lucetti, D.L.; Lucetti, E.C.P.; Silva, J.M.F.L.; Santos, F.A.V.; Medeiros, C.R.; Oliveira, G.M.M.; et al. Modulation of the Antibiotic Activity by Extracts from Amburana cearensis A. C. Smith and Anadenanthera macrocarpa (Benth.) Brenan. BioMed Res. Int. 2013, 2013, 640682. [CrossRef] [PubMed]

46. Da Silva, V.F.; Franco, I.; Damasceno, T.E.F.; Almeida, J.; Da Costa, M.M. Potencial antimicrobiano de extratos etanólicos de plantas frente a bacilos gram negativos isolados da mucosa cérvico-vaginal de ovelhas criadas na região de Petrolina-PE. Semin. Ciências Agrárias 2014, 35, 883-890. [CrossRef]

47. Peixoto, R.M.; Silva, W.E.L.; ALmeida, J.R.G.S.; Branco, A.; Costa, M.M. Antibacterial potential of native plants from the caatinga biome against staphylococcus spp. isolates from small ruminants with mastitis. Rev. Caatinga 2016, 29, 758-763. [CrossRef]

48. De Oliveira, A.K.; Coelho, M.D.F.B.; Diógenes, F.E.P. Allelopathic activity of amburana cearensis seed extracts on melon emergence. Rev. Caatinga 2020, 33, 274-280. [CrossRef]

49. Andrade, J.C.; Silva, A.R.P.; Santos, A.T.L.; Freitas, M.A.; Carneiro, J.N.P.; Gonçalo, M.I.P.; Morais-Braga, M.F.B. UPLC-MS-ESIQTOF characterization and evaluation of the antibacterial and modulatory antibiotic activity of Ziziphus joazeiro Mart. aqueous extracts. S. Afr. J. Bot. 2019, 123, 105-112. [CrossRef]

50. Dos Santos, P.H.A.; Dos Santos, I.S.; Melo, V.M.M.; Vasconcelos, I.M.; Carvalho, A.D.O.; Gomes, V.M. Partial characterization and antimicrobial activity of peptides from Amburana cearensis seeds against phytopathogenic fungi and yeasts. Acta Physiol. Plant. 2009, 32, 597-603. [CrossRef] 
51. Dias, M.C.; Pinto, D.C.G.A.; Silva, A.M.S. Plant Flavonoids: Chemical Characteristics and Biological Activity. Molecules 2021, 26, 5377. [CrossRef]

52. Leal, L.; Matos, M.; Matos, F.; Ribeiro, R.; Ferreira, F.; Viana, G. Antinociceptive and antiedematogenic effects of the hydroalcoholic extract and coumarin from Torresea cearensis Fr. All. Phytomedicine 1997, 4, 221-227. [CrossRef]

53. Bentley, G.; Newton, S.; Starr, J. Studies on the antinociceptive action of $\alpha$-agonist drugs and their interactions with opioid mechanisms. J. Cereb. Blood Flow Metab. 1983, 79, 125-134. [CrossRef]

54. Leal, L.; Ferreira, A.; Bezerra, G.; Matos, F.; Viana, G. Antinociceptive, anti-inflammatory and bronchodilator activities of Brazilian medicinal plants containing coumarin: A comparative study. J. Ethnopharmacol. 2000, 70, 151-159. [CrossRef]

55. Marinho, M.G.V.; Brito, A.G.; Carvalho, K.A.; Bezerra-Santos, C.R.; Andrade, L.H.C.; Barbosa-Filho, J.M.; Piuvezam, M.R. Amburana cearensis e cumarina imunomodulam os níveis de anticorpos antígeno-especffico em camundongos BALB/c sensibilizados com ovalbumina. Acta Farm. Bonaer. 2004, 23, 47-52.

56. Leal, L.K.A.M.; Nechio, M.; Silveira, E.R.; Canuto, K.M.; Fontenele, J.B.; Ribeiro, R.A.; Viana, G.S.B. Anti-inflflammatory and smooth muscle relaxant activities of the hydroalcoholic extract and chemical constituents from Amburana cearensis A. C. Smith. Phytotherapy Res. 2003, 17, 335-340. [CrossRef]

57. Oliveira, R.R.B.; Góis, R.M.O.; Siqueira, R.S.; Almeida, J.R.G.S.; Lima, J.T.; Nunes, X.P.; Oliveira, V.R.; Siqueira, J.S.; Quintans, J. Antinociceptive effect of the ethanolic extract of Amburana cearensis (Allemão) A.C. Sm., Fabaceae, in rodents. Rev. Bras. Farm. 2009, 19, 672-676. [CrossRef]

58. Ariyo, O.O.; Ajayi, A.M.; Ben-Azu, B.; Aderibigbe, A.O. Anti-nociceptive and anti-inflammatory activities of ethanol extract and fractions of Morus mesozygia Stapf (Moraceae) leaves and its underlying mechanisms in rodents. J. Ethnopharmacol. 2020, 259, 112934. [CrossRef] [PubMed]

59. Lima, L.R.; Cavalcante, R.R.L.; Martins, M.C.C.; Parente, D.M.; Cavalcante, A.A.M.C. Avaliação da atividade antiedematogênica, antimicrobiana e mutagênica das sementes de Amburana cearensis (A. C. Smith) (Imburana-de-cheiro). Rev. Bras. Plantas Med. 2013, 15, 415-422. [CrossRef]

60. Leal, L.K.A.M.; Canuto, K.M.; Costa, K.C.D.S.; Júnior, H.; Vasconcelos, S.; Silveira, E.R.; Ferreira, M.V.P.; Fontenele, J.; Andrade, G.M.; Viana, G.S.D.B. Effects of Amburoside A and Isokaempferide, Polyphenols from Amburana cearensis, on Rodent Inflammatory Processes and Myeloperoxidase Activity in Human Neutrophils. Basic Clin. Pharmacol. Toxicol. 2009, 104, 198-205. [CrossRef] [PubMed]

61. Canuto, K.M.; Leal, L.K.A.M.; Lopes, A.A.; Coleman, C.M.; Ferreira, D.; Silveira, E.R. Amburanins A and B from Amburana cearensis: Daphnodorin-Type Biflavonoids that Modulate Human Neutrophil Degranulation. J. Braz. Chem. Soc. 2014, 25, 639-647. [CrossRef]

62. Lopes, A.D.A.; Magalhães, T.R.; Uchôa, D.E.D.A.; Silveira, E.R.; Azzolini, A.E.C.S.; Kabeya, L.M.; Lucisano-Valim, Y.M.; Vasconcelos, S.; Viana, G.S.D.B.; Leal, L.K.A.M. Afrormosin, an Isoflavonoid from Amburana cearensis A. C. Smith, Modulates the Inflammatory Response of Stimulated Human Neutrophils. Basic Clin. Pharmacol. Toxicol. 2013, 113, 363-369. [CrossRef]

63. Krishnaiah, D.; Sarbatly, R.; Nithyanandam, R. A review of the antioxidant potential of medicinal plant species. Food Bioprod. Process. 2011, 89, 217-233. [CrossRef]

64. Li, X.; Fei, Z.; Fei, F.; Su, N. Neuroprotection mediated by natural products and their chemical derivatives. Neural Regen. Res. 2020, 15, 2008-2015. [CrossRef]

65. Pierdoná, T.; Araújo, E.; Amaral, H.; Freitas, L.; Viana, G.; Silveira, E.; Leal, L.P. 1.g.103 Evaluation of the neuroprotective effects of bioproducts from Amburana cearensis on microglial cells. Eur. Neuropsychopharmacol. 2014, 24, S264. [CrossRef]

66. Lataliza, A.A.B.; Cavalli, J.; Amarante, C.B.; Barbosa, D.B.; Brandão, M.A.F.; Dutra, R.C.; Rapozo, N.R.B. Antioxidant, Cytotoxic, Antiproliferative And Acetylcholinesterase Inhibition Properties of the Extract from Amburana cearensis. J. Multidiscip. Eng. Sci. Technol. 2019, 6, 9336-9343.

67. Costa-Lotufo, L.V.; Jimenez, P.C.; Wilke, D.V.; Leal, L.K.; Cunha, G.M.A.; Silveira, E.R.; Canuto, K.M.; Viana, G.S.B.; Moraes, M.E.A.; de Moraes, M.O.; et al. Antiproliferative Effects of Several Compounds Isolated from Amburana cearensis A. C. Smith. Z. Nat. C 2003, 58, 675-680. [CrossRef]

68. Rice, E.L. Allelopathy: An overview. In Allelochemicals: Role in Agriculture and Forestry; Waller, G.R., Ed.; American Chemical Society: Washington, DC, USA, 1987; pp. 8-22.

69. Felix, A.R.Z.; Ono, E.O.; Pereira, C.S.; Rodrigues, J.D.; Pieri, C. Efeitos Alelopáticos da Amburana cearensis L. (Fr. All.) AC Smith na Germinação de Sementes de Alface (Lactuca sativa L.) e de Rabanete (Raphanus sativus L.). Rev. Bras. Fisiol. Veg. 2007, 5, 138-140.

70. Lessa, B.F.T.; Silva, M.L.S.; Barreto, J.H.B.; Oliveira, A.B. Allelopathics effects of aqueous extracts of leaves of Amburana cearensis and Plectranthus barbatus on the germination of Amaranthus deflexus. Rev. Ciências Agrárias 2017, 40, 79-86. [CrossRef]

71. De Oliveira, A.K.; Coelho, M.D.F.B.; Torres, S.B.; Diógenes, F.; Ésio, P. Allelopathy by extracts of Caatinga species on melon seeds. Semin. Ciências Agrárias 2016, 37, 557-566. [CrossRef]

72. Tuyen, P.T.; Xuan, T.D.; Anh, T.T.T.; Van, T.M.; Ahmad, A.; Elzaawely, A.A.; Khanh, T.D. Weed Suppressing Potential and Isolation of Potent Plant Growth Inhibitors from Castanea crenata Sieb. et Zucc. Molecules 2018, 23, 345. [CrossRef] [PubMed]

73. Trevisan, M.T.S.; Macedo, F.V.V.; Meent, M.V.D.; Rhee, I.K.; Verpoorte, R. Seleção de plantas com atividade anticolinasterase para tratamento da doença de Alzheimer. Química Nova 2003, 26, 301-304. [CrossRef]

74. Sharangi, A.B.; Das, S. Healing indigestion: A phytotherapeutic review. Adv. Tradit. Med. 2020, 20, 1-17. [CrossRef] 
75. Barberino, R.; Barros, V.; Menezes, V.; Santos, L.; Araújo, V.; Queiroz, M.; Almeida, J.; Palheta, R.; Matos, M. Amburana cearensis leaf extract maintains survival and promotes in vitro development of ovine secondary follicles. Zygote 2016, 24, 277-285. [CrossRef]

76. Menezes, V.G.; Barberino, R.D.S.; Gouveia, B.B.; Gonçalves, R.J.D.S.; Almeida, J.R.G.D.S.; de Matos, M.H.T. Extract of Amburana cearensis maintains the survival of ovine preantral follicles during long-term ovarian tissue transport and promotes primordial follicle activation after in vitro culture. Semin. Ciências Agrárias 2018, 39, 2001-2016. [CrossRef]

77. Farias, D.F.; Cavalheiro, M.G.; Viana, M.P.; Queiroz, V.A.; Rocha-Bezerra, L.C.; Vasconcelos, I.M.; Morais, S.M.; Carvalho, A.F Water extracts of Brazilian leguminous seeds as rich sources of larvicidal compounds against Aedes aegypti L. An. Acad. Bras. Ciências 2010, 82, 585-594. [CrossRef] [PubMed]

78. De Melo, B.A.; Molina-Rugama, A.J.; Haddi, K.; Leite, D.T.; De Oliveira, E.E. Repellency and Bioactivity of Caatinga Biome Plant Powders against Callosobruchus maculatus (Coleoptera: Chrysomelidae: Bruchinae). Fla. Èntomol. 2015, 98, 417-423. [CrossRef]

79. Dantas, A.C.D.S.; Araujo, A.D.C.; Pacheco, A.G.M.; Branco, A.; Sangioni, L.A.; Almeida, J.R.G.D.S.; Horta, M.C. Acaricidal activity of Amburana cearensis on the cattle tick Rhipicephalus (Boophilus) microplus. Ciência Rural. 2015, 46, 536-541. [CrossRef]

80. Nunes, A.R.; Rodrigues, A.L.M.; de Queiróz, D.B.; Vieira, I.G.P.; Neto, J.F.C.; Junior, J.T.C.; Tintino, S.R.; de Morais, S.M.; Coutinho, H.D.M. Photoprotective potential of medicinal plants from Cerrado biome (Brazil) in relation to phenolic content and antioxidant activity. J. Photochem. Photobiol. B Biol. 2018, 189, 119-123. [CrossRef]

81. Monteiro, R.M.; Carneiro, I.D.S.; de Sousa, F.D.; Teixeira, M.J.; Dourado, R.C.M.; Moreira, R.D.A.; Moreira, A.C.D.O.M. Antileishmanial Activity of Coumarin from Amburana cearensis Seeds. OALib 2017, 4, 1-10. [CrossRef]

82. Leal, L.K.A.M.; Fonseca, F.N.; Pereira, F.A.; Canuto, K.M.; Felipe, C.F.B.; Fontenele, J.B.; Pitombeira, M.V.; Silveira, E.R.; Viana, G.S.B. Protective Effects of Amburoside A, a Phenol Glucoside from Amburana cearensis, against CCl4-Induced Hepatotoxicity in Rats. Planta Med. 2008, 74, 497-502. [CrossRef] 